\title{
Docetaxel/Goserelin Regimen
}

National Cancer Institute

\section{Source}

National Cancer Institute. Docetaxel/Goserelin Regimen. NCI Thesaurus. Code C160517.

A regimen consisting of docetaxel and goserelin that can be used for the treatment of prostate cancer. 